\title{
História e Imagens, de Eduardo França Paiva: interface com a Nova História Cultural
}

\author{
Marinalva Aguiar Teixeira Rocha ${ }^{1}$ \\ PAIVA, Eduardo França. História \& Imagens. 2 ed. Belo Horizonte:
} Autêntica, 2006.

A Nova História Cultural ampliou-se, na medida em que abriu um leque de possibilidades de registros, permitindo ao pesquisador, por meio de diversas fontes, entre elas a iconografia, diversificar sua forma de discussão. Nesse sentido, assevera Paiva (2006, p. 17) que "a iconografia é tomada agora como registro histórico realizado por meio de ícones, de imagens pintadas, desenhadas, impressas ou imaginadas e, ainda, esculpidas, ... gravadas em material fotográfico e cinematográfico".

A imagem, ao ser vista e percebida como artefato que representa aspecto relacionado à cultura de uma época, revela valores dessa época, evidenciando que a produção iconográfica, enquanto objeto de pesquisa, alarga seu campo de informações, o que permite conhecer a extensão dos contextos socioculturais em que as imagens foram produzidas. Nesse sentido, é importante dizer que a obra História e Imagens, de Eduardo França Paiva, é um texto que apresenta, por meio das imagens ali expostas, uma discussão precisa acerca da historiografia. São registros que permitem ao pesquisador refletir sobre várias formas de análise iconográfica. Aspecto que leva a entender que a imagem é uma rica fonte que colabora para o conhecimento e esclarecimento sobre os acontecimentos históricos e culturais. Vale dizer, ainda, que as imagens para serem analisadas, enquanto fonte de pesquisa, é importante que o pesquisador perceba os detalhes, suas minúcias, levando em consideração os interesses do produtor, o tempo em que foram produzidas, enfim, reconheça as suas potencialidades.

Mesmo com a vastidão de fontes existentes atualmente, a iconografia é um dos recursos que os estudiosos têm lançado mão, cada vez mais, com o intuito de

\footnotetext{
${ }^{1}$ Doutoranda em História pela Universidade do Rio dos Sinos-UNISINOS; Prof ${ }^{a}$ Assistente da Universidade Estadual do Maranhão- Campus Caxias.
} 
proceder às representações de aspectos históricos e culturais, resultantes das ações de uma sociedade. Nesse sentido, Paiva (2006, p. 14) assegura que "as imagens são representações que se produzem nas e sobre as variadas dimensões da vida no tempo e no espaço". O citado historiador destaca que dada a amplitude do universo iconográfico, optou por evidenciar em sua obra a pintura, desenhos, imagens esculpidas e algumas imagens de memória. Em se tratando de representação, o autor destaca em sua obra que, ao longo dos tempos, algumas imagens foram sendo incorporadas ao nosso imaginário, é o caso da caveira, que mesmo tendo perdido alguns dos seus atributos, permanece viva na memória dos sujeitos, tal imagem continua lembrando a morte, "a representação atual da morte como caveira adquiriu novos atributos, mais próprios de nosso tempo" (PAIVA, 2006, p. 36).

Considerando que as imagens nos estudos da Nova História Cultural não se justificam pela sua capacidade de ilustração, mas pela possibilidade de estabelecer diálogo com acontecimentos de outras épocas, como também para produção de conhecimento histórico-cultural, verifica-se na obra intitulada História e Imagens uma gama de imagens iconográficas que representam eventos de um dado período, e que leva o leitor a perceber que as diversas informações ali inseridas têm a ver com a época em que foram produzidas, com o ponto de vista de seu produtor, com o contexto etc. Para o autor da citada obra,

Os contextos diferenciados dão, portanto, significados e juízos diversos às imagens. O distanciamento no tempo entre o observador, o objeto de observação e 0 autor do objeto também imprime diferentes entendimentos, uma vez que, ... as leituras são sempre realizadas no presente, em direção ao passado (PAIVA, 2006, p. 31).

A Nova História Cultural concebe a imagem como um recurso de registro que se reporta ao passado, como também dotada de características que a eleva ao grau de categoria documental. Assim, as imagens iconográficas descritas por Eduardo França Paiva refletem "sobre história cultural, que toma as representações icônicas e figurativas como pontos centrais de reflexão" (PAIVA, 2006, p. 32). Dessa forma, a título de exemplo, evidencia-se na obra do estudioso (p. 44) as representações da figura feminina, associada ao pecado. Tal representação se originou na Bíblia. Considerando a criação feminina a partir da costela de Adão, a 
mulher é, por isso, vista como um ser inferior. Acrescenta, ainda, o Livro Sagrado que essa mulher, denominada Eva, por ter cometido um grande delito, ou seja, provado do fruto do pecado, levando Adão a ter a mesma atitude, fez com que fosse instituído o pecado original, o que a levou a ser tida como representação do pecado, "exatamente por conta dessa associação entre mulher e o pecado é que ela também foi tomada como agente do mal e até mesmo como manifestação humanizada do próprio demônio" (PAIVA, 2006, p. 45).

A partir dessas ideias, várias imagens da mulher foram pintadas para simbolizar os seus feitos em diversas épocas. Como ilustra Paiva em História e Imagens, vê-se, ainda, a figura da mulher piedosa, maternal, associada ao da Virgem Maria, são representações que se opõem às associações feitas à figura de Eva, aquela que contrariou as Leis de Deus. Paiva se refere, ainda, à figura da mulher dita independente, livre, dominadora, qualidades essas que, de acordo com a antiga tradição, eram próprias dos homens. Essa representação mostra uma mulher que, por ser realizada profissionalmente, se torna infeliz no amor. Tal infelicidade é recebida como castigo devido a sua astúcia de tentar superar a figura masculina.

Paiva (2006) traz em sua obra um capítulo intitulado Cenas do Brasilséculos $X V I I I, X I X$ e $X X$. Nele, o autor, a partir de algumas imagens, promove ao leitor um retorno a acontecimentos passados, mas que, de acordo com o olhar de cada um, as imagens são ressignificadas, considerando que, segundo Paiva (p. 55) "elas adquirem novos significados a cada nova leitura, a cada nova época, e por isso elas também oferecem novas respostas às novas indagações que são colocadas".

Segundo as proposições do autor, não é possível se reproduzir uma realidade tal qual fora, mas muitos artistas tentaram pintar e esculpir imagens que reproduzissem a vida cotidiana no Brasil. Essa tentativa, obviamente, não alcançou o real, mas conseguiu esboçar uma imagem aproximada do que se vivia. As cenas revestiam-se de valores da época em que viviam e valores do próprio pintor/escultor, como também de aspectos do cotidiano que eram observados pelo artista. Desse modo, citam-se as imagens retratadas por Carlos Julião, em que, durante suas andanças pelo Brasil, registra o cotidiano de escravos e libertos e, sobretudo, das mulheres. $O$ artista registrou o que Ihe chamava atenção, o que the 
causava estranhamento. Essas imagens mostram escravos desfrutando de posições social e econômica que lhes garantia o direito à aquisição de bens e a uma vida tranquila. Registram, ainda, as indumentárias, as joias utilizadas por negras alforriadas, o que poderia significar, tão somente, ostentação. A Nova História Cultural, nesse caso, vai permitir ao historiador fazer novas indagações a respeito daquilo que está evidenciado na imagem, visto que esse novo paradigma historiográfico propicia novas formas de abordagem, permitindo, por exemplo, a construção histórica das massas anônimas.

É o olhar do pesquisador da historiografia cultural que observará nas imagens aspectos pouco evidentes, tais como as diferentes práticas culturais. É o caso, por exemplo, da litografia Venda em Recife, citada por Paiva que mostra o quão é possível analisar a mesma imagem, sob diferentes óticas, em diferentes épocas. Tal imagem, ao longo dos tempos, foi tida como demonstração da importância do comércio nas regiões coloniais, dado o fluxo contínuo de pessoas circulando pelas ruas e pelo comércio, isso referendado no registro do artista. Essa imagem pode ser percebida com um olhar mais intenso, profundo, menos inocente. Podendo, dessa forma, observar nesse cenário nuances que revelam, segundo Paiva (2006) a "complexidade cultural em torno da venda", por exemplo, o convívio entre negros, brancos e índios; o tipo de mercadoria que circulava dentro e fora do comércio; mulher negra vendendo produtos a brancas, enfim, a litografia apresentada, sendo vista por um ângulo diferente de outras épocas, tal como se apresenta a História Vista de Baixo, em que focaliza, por exemplo, a trajetória dos anônimos. Homens e mulheres comuns, que antes tinham suas histórias ignoradas, passam a fazer parte da historiografia.

Com essas análises, observa-se que a cultura visual como prática de pesquisa tem encontrado ressonâncias em outras áreas do conhecimento. A leitura da obra História e Imagens, de Eduardo França Paiva permitiu que se entendessem que os registros iconográficos, ao deixarem de ser utilizados apenas como ilustrações, vislumbram novos significados, tornando-os relevantes para as pesquisas de cunho histórico e cultural. Para tanto, é necessário "saber indagá-los e deles escutar as respostas" (PAIVA, 2006, p.17).

Data de Submissão: 03/03/17

Data de Aprovação: 06/05/17 